\title{
Candida galacta comb. nov., a New Combination for Candida apis var. galacta
}

\author{
FWU-LING LEE, ${ }^{1,2}$ CHING-FU LEE, ${ }^{2}$ SANAE OKADA, ${ }^{2}$ TAI UCHIMURA, ${ }^{1}$ KAZUO KOMAGATA, ${ }^{1 *}$ \\ AND MICHIO KOZAKI ${ }^{1}$ \\ Department of Agricultural Chemistry ${ }^{1}$ and Culture Collection Center, ${ }^{3}$ Tokyo University of Agriculture, 1-1-1, \\ Sakuragaoka, Setagaya-ku, Tokyo 156, Japan, and Culture Collection and Research Center, Food \\ Industry Research and Development Institute, Hsin-chu 300, Taiwan, Republic of China ${ }^{2}$
}

\begin{abstract}
Candida apis (Lavie ex van Uden et Vidal-Leiria) Meyer et Yarrow differs from Candida apis (Lavie ex van Uden et Vidal-Leiria) Meyer et Yarrow var. galacta Golubev et Bab'eva in DNA base composition, DNA relatedness, ubiquinone system, and cellular fatty acid composition. We propose that $C$. apis var. galacta should be elevated to species level and named Candida galacta comb. nov. The type strain of this species is strain CBS 6939 (= NRIC [Nodai Research Institute Culture Collection, Tokyo University of Agriculture, Tokyo, Japan] $1910=$ CCRC [Culture Collection and Research Center, Food Industry Research and Development Institute, Taiwan, Republic of China] 22278 = IFO 10031).
\end{abstract}

Torulopsis apis Lavie ex van Uden et Vidal-Leiria was isolated in 1954 from bees; this name was validated in 1970 (10). Torulopsis apis Lavie ex van Uden et Vidal-Leiria var. galacta Golubev et Bab'eva was isolated from cocoons of red ants belonging to the Formica rufa L. group; this name was published in 1977, and this organism was differentiated from $T$. apis by its spheroidal cell shape, its inability (or very weak ability) to assimilate raffinose, and its inability to grow in vitamin-free medium (4). As the genera Candida and Torulopsis were combined into the genus Candida by Yarrow and Meyer (12), T. apis and T. apis var. galacta were transferred to the genus Candida as Candida apis and Candida apis var. galacta, respectively. A difference of 2.8 mol\% between the $\mathrm{G}+\mathrm{C}$ content of $C$. apis $(48.8 \mathrm{~mol} \%)$ and the $\mathrm{G}+\mathrm{C}$ content of $C$. apis var. galacta $(46.0 \mathrm{~mol} \%)$ was reported by Barnett et al. (1).

In this paper we describe a chemotaxonomic comparison of $C$. apis and $C$. apis var. galacta, as well as other osmotolerant, insect-associated yeasts, that was based on DNA base composition, DNA relatedness, ubiquinone system, and cellular fatty acid composition data.

The strains which we studied are shown in Table 1 along with their sources of isolation. Morphological and physiological characteristics were determined by the methods described by van der Walt and Yarrow (9).

To determine DNA base composition and levels of DNA relatedness, cells were grown in YM broth containing 3\% sodium chloride and were collected at the late logarithmic phase of growth. Isolation and purification of DNA were performed by the method of Yamada et al. (11). The purified DNA was hydrolyzed to nucleosides as described by Tamaoka and Komagata (8), and the hydrolysate was analyzed by reversed-phase high-performance liquid chromatography to determine DNA base composition. Levels of DNA relatedness were determined by the photobiotin labeling microplate method described by Yamada et al. (11).

To determine ubiquinone systems, cells were grown in the liquid medium of Billon-Grand (2) supplemented with $3 \%$ sodium chloride and were collected at the early stationary phase of growth. The cells were lyophilized, and ubiquino-

\footnotetext{
* Corresponding author.
}

nes were extracted and purified by the method of Collins et al. (3). The purified quinones were analyzed by high-performance liquid chromatography.

To determine cellular fatty acid composition, all strains were cultivated in the liquid medium of Smit et al. (7) containing $3 \%$ sodium chloride and were collected at the late stationary phase of growth. Fatty acids were analyzed by gas chromatography, using the method described by Ikemoto et al. (5).

C. apis NRIC $1909^{\mathrm{T}}(\mathrm{T}=$ type strain) and $C$. apis var. galacta NRIC $1910^{\mathrm{T}}$ differed in assimilation of raffinose as described by Golubev and Bab'eva (4), Meyer et al. (6), and Barnett et al. (1). C. apis and $C$. apis var. galacta were separated from three other species by the fermentation of carbohydrates.

DNA base compositions were 44.6 and $50.2 \mathrm{~mol} \% \mathrm{G}+\mathrm{C}$ for $C$. apis NRIC $1909^{\mathrm{T}}$ and $C$. apis var. galacta NRIC $1910^{\mathrm{T}}$, respectively, and 44.3 to $46.6 \mathrm{~mol} \% \mathrm{G}+\mathrm{C}$ for three other species listed in Table 2. As determined by Barnett et al. (1), the DNA base compositions were $48.8 \mathrm{~mol} \% \mathrm{G}+\mathrm{C}$ (as determined by the thermal denaturation method) and 46.0 mol\% $\mathrm{G}+\mathrm{C}$ (as determined by a chemical method) for $C$. apis and $C$. apis var. galacta, respectively, while a difference of $5.6 \mathrm{~mol} \% \mathrm{G}+\mathrm{C}$ (as determined by high-performance liquid chromatography) between $C$. apis and $C$. apis var. galacta DNA base compositions was found in this study. These results support the view that these yeasts represent distinct taxa.

As shown in Table 2,C. apis exhibited 13\% DNA relatedness to the type strain of $C$. apis var. galacta, and low levels ( 7 to $29 \%$ ) of DNA relatedness to the type strains of the other three species studied. $C$. apis var. galacta exhibited $6 \%$ DNA relatedness to the type strain of $C$. apis and low levels ( 5 to $7 \%$ ) of DNA relatedness to the type strains of the three other species studied.

C. apis, Candida apicola, Candida bombi, and Candida bombicola had Q-9 as the major component of their ubiquinone systems, while $C$. apis var. galacta had Q-8 as its major component. The difference in the quinone systems clearly indicated that $C$. apis var. galacta should be separated from $C$. apis and the three other species.

For all of the strains tested, oleic acid was a major fatty acid component (range, 66 to $80 \%$ of the total fatty acids). Myristic acid, palmitic acid, palmitoleic acid, and stearic 
TABLE 1. Strains studied

\begin{tabular}{lccccc}
\hline \multirow{2}{*}{ Taxon } & \multicolumn{4}{c}{ Strain designations $^{a}$} & \multirow{2}{*}{ Source } \\
\cline { 2 - 5 } & NRIC & CCRC & IFO & CBS & \\
\hline $\begin{array}{l}\text { C. apis } \\
\text { C. } \text { apis var. }\end{array}$ & $1909^{\mathrm{T}}$ & $22486^{\mathrm{T}}$ & $10262^{\mathrm{T}}$ & $2674^{\mathrm{T}}$ & Bee \\
$\begin{array}{l}\text { galacta } \\
\text { C. apicola }\end{array}$ & $22278^{\mathrm{T}}$ & $10031^{\mathrm{T}}$ & $6939^{\mathrm{T}}$ & $\begin{array}{c}\text { Cocoons of red } \\
\text { ants }\end{array}$ \\
C. bombi & $1802^{\mathrm{T}}$ & $22277^{\mathrm{T}}$ & $10261^{\mathrm{T}}$ & $2868^{\mathrm{T}}$ & $\begin{array}{c}\text { Intestinal tract } \\
\text { of a bee }\end{array}$ \\
C. bombicola & $1807^{\mathrm{T}}$ & $22389^{\mathrm{T}}$ & $10267^{\mathrm{T}}$ & $5836^{\mathrm{T}}$ & Bee \\
\hline
\end{tabular}

${ }^{a}$ NRIC, Nodai Research Institute Culture Collection, Tokyo University of Agriculture, Tokyo, Japan; CCRC, Culture Collection and Research Center, Food Industry Research and Development Institute, Hsinchu, Taiwan, Republic of China; IFO, Institute for Fermentation, Osaka, Japan; CBS, Centraalbureau voor Schimmelcultures, Delft, The Netherlands.

acid were detected as minor components (less than $20 \%$ of the total fatty acids). However, the fatty acid patterns of the strains which we studied were not significantly different.

The DNA comparison and ubiquinone system data indicate that $C$. apis var. galacta should be considered a species that is genetically distinct species from $C$. apis, $C$. apicola, C. bombi, and C. bombicola. Therefore, we propose that $C$. apis var. galacta should be elevated to species level as Candida galacta comb. nov.

Transfer of $\boldsymbol{C}$. apis var. galacta to Candida galacta comb. nov. Candida galacta (Golubev et Bab'eva) Lee, Lee, Okada, Hsu, Uchimura, Komagata, et Kozaki comb. nov. [basonym, Torulopsis apis Lavie ex van Uden et VidalLeiria var. galacta Golubev et Bab'eva (4); synonym, Candida apis (Lavie ex van Uden et Vidal-Leiria) Meyer et Yarrow var. galacta Golubev et Bab'eva 1978 (12)].

TABLE 2. DNA base compositions and levels of DNA relatedness of the Candida species studied

\begin{tabular}{|c|c|c|c|c|c|c|}
\hline \multirow[b]{2}{*}{$\begin{array}{c}\text { Source of } \\
\text { unlabeled DNA }\end{array}$} & \multirow[b]{2}{*}{$\begin{array}{l}\mathrm{G}+\mathrm{C} \\
\text { content } \\
\text { (mol\%) }\end{array}$} & \multicolumn{5}{|c|}{$\begin{array}{l}\% \text { Relatedness to labeled } \\
\text { DNA from: }\end{array}$} \\
\hline & & 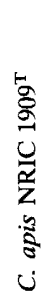 & 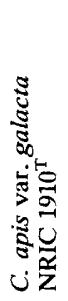 & 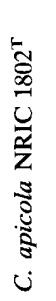 & 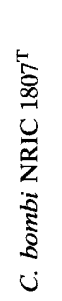 & 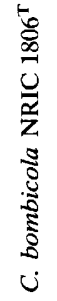 \\
\hline C. apis NRIC $1909^{\mathrm{T}}$ & 44.6 & 100 & 13 & 28 & 29 & 7 \\
\hline C. apis var. galacta NRIC $1910^{\mathrm{T}}$ & 50.2 & 6 & 100 & 7 & 6 & 5 \\
\hline C. apicola NRIC $1802^{\mathrm{T}}$ & 44.3 & 6 & 4 & 100 & 18 & 4 \\
\hline C. bombi NRIC $1807^{\mathrm{T}}$ & 46.6 & 14 & 12 & 12 & 100 & 9 \\
\hline C. bombicola NRIC $1806^{\mathrm{T}}$ & 46.6 & 12 & 12 & 7 & 24 & 100 \\
\hline
\end{tabular}

Typus: CBS 6939 (= NRIC $1910=$ CCRC $22278=$ IFO 10031).

Characteristics other than those given by Golubev and Bab'eva in their description of this species (4) are given below.

Major ubiquinone system: Q-8.

DNA base composition: $50.2 \mathrm{~mol} \% \mathrm{G}+\mathrm{C}$ (as determined by high-performance liquid chromatography) or $46.0 \mathrm{~mol} \%$ $\mathrm{G}+\mathrm{C}(4)$.

We thank I. Banno, Institute for Fermentation, Osaka, and T. Nakase, Japan Collection of Microorganisms, for their invaluable suggestions and P. C. Ma, T. Y. Liu, and W. H. Hsu, Food Industry Research and Development Institute, Taiwan, Republic of China, for their encouragement. We also thank Y. Takeuchi for providing the subcultures and the Centraalbureau voor Schimmelcultures, Delft, The Netherlands, for supplying authentic strains.

\section{REFERENCES}

1. Barnett, J. A., R. W. Payne, and D. Yarrow. 1990. Descriptions of the species, arranged alphabetically, p. 79-695. In Yeasts: characteristics and identification, 2 nd ed. Cambridge University Press, Cambridge.

2. Billon-Grand, G. 1989. Influence on minor peaks of coenzyme Q of the glucose concentration in the culture medium, the stage of the growth cycle, and the duration of the coenzyme $Q$ extraction: required conditions for determining the minor coenzyme Q. J. Gen. Appl. Microbiol. 35:261-268.

3. Collins, M. D., T. Pirouz, and M. Goodfellow. 1977. Distribution of menaquinones in actinomycetes and corynebacteria. J. Gen. Appl. Microbiol. 100:221-230.

4. Golubev, W. I., and I. P. Bab'eva. 1977. Torulopsis apis var. galacta var. nov. Int. J. Syst. Bacteriol. 27:165-167.

5. Ikemoto, S., K. Katoh, and K. Komagata. 1978. Cellular fatty acid composition in methanol-utilizing bacteria. J. Gen. Appl. Microbiol. 24:41-49.

6. Meyer, S. A., D. G. Ahearn, and D. Yarrow. 1984. Genus 4. Candida Berkhout, p. 585-844. In N. J. W. Kreger-van Rij (ed.), The yeasts, a taxonomic study. Elsevier Science Publishers B. V., Amsterdam.

7. Smit, E. J., J. P. J. v. d. Westhuizem, J. L. Kock, and P. M. Lategan. 1987. A yeast identification method: the influence of culture age on the cellular long-chain fatty acid composition of three selected basidomycetous yeasts. Syst. Appl. Microbiol. 10:38-41.

8. Tamaoka, J., and K. Komagata. 1984. Determination of DNA base composition by reversed-phase high performance liquid chromatography. FEMS Microbiol. Lett. 25:125-128.

9. van der Walt, J. P., and D. Yarrow. 1984. Methods for isolation, maintenance, classification and identification of yeasts, p. 45104. In N. J. W. Kreger-van Rij (ed.), The yeasts, a taxonomic study. Elsevier Science Publishers B. V., Amsterdam.

10. van Uden, N., and M. Vidal-Leiria. 1970. Genus 10. Torulopsis Berlese, p. 1235-1308. In J. Lodder (ed.), The yeasts, a taxonomic study. North-Holland Publishing Co., Amsterdam.

11. Yamada, Y., Y. Kaneko, and K. Mikata. 1990. Identification of 38 brewing yeasts maintained in Institute for Fermentation, Osaka, collection. Bull. Japan Fed. Culture Collections 6:76-85. (In Japanese.)

12. Yarrow, D., and S. A. Meyer. 1978. Proposal for amendment of the diagnosis of the genus Candida Berkhout nom. cons. Int. J. Syst. Bacteriol. 28:611-615. 